\title{
In vivo studies on non-viral transdifferentiation of liver cells towards pancreatic $\beta$ cells
}

\author{
Abdullah Cim*, Greta J Sawyer, Xiaohong Zhang, Haibin Su, Louise Collins, Peter Jones ${ }^{1}$, \\ Michael Antoniou ${ }^{2}$, Jean-Paul Reynes ${ }^{3}$, Hans-Joachim Lipps ${ }^{4}$ and John W Fabre
}

Department of Hepatology and Transplantation, King's College London School of Medicine, James Black Centre, 125 Coldharbour Lane, London SE5 9NU, UK

${ }^{1}$ Diabetes Research Group, School of Biomedical and Health Sciences, King's College London, Guy's Campus, London SE1 9UL, UK

${ }^{2}$ Department of Medical and Molecular Genetics, King's College London School of Medicine, Guy's Hospital, London SE1 9RT, UK

${ }^{3}$ InvivoGen, Inc., 5 Rue Jean Rodier, F-31400 Toulouse, France

${ }^{4}$ Institut für Zellbiologie, Centre for Biomedical Education and Research, Universitat Witten/Herdecke, Stockumer Strasse 10, 58448 Witten, Germany

(Correspondence should be addressed to J W Fabre; Email: john.fabre@kcl.ac.uk)

*(A Cim is now at Department of Medical Genetics, Dicle University, Diyarbak 21280, Turkey)

\begin{abstract}
Transdifferentiation in vivo is an attractive option for autologous replacement of pancreatic $\beta$ cells in patients with type 1 diabetes. It has been achieved by adenoviral delivery of genes for transcription factors in the liver and pancreas of hyperglycaemic mice. However, these viral approaches are not clinically applicable. We used the hydrodynamic approach to deliver genes $P d x 1$, Ngn3 (Neurog3) and MafA singly and in combination to livers of normoglycaemic rats. Five expression plasmids were evaluated. Livers were removed 1, 3, 7, 14 and 28 days after gene delivery and assayed by quantitative PCR, semi-quantitative PCR and immunohistology. Functional studies on hyperglycaemic rats were performed. The highest and most sustained expression was from a CpG-depleted plasmid $(\mathrm{pCpG})$ and a plasmid with an in-frame scaffold/matrix
\end{abstract}

attachment region $((\mathrm{pEPI}(\mathrm{CMV}))$. When Pdx1, Ngn3 and MafA were delivered together to normoglycaemic rats with these plasmids, insulin mRNA was detected at all time points and was $\sim 50$-fold higher with pCpG. Insulin mRNA content of livers at days 3 and 7 was equivalent to that of a pancreas, with scattered insulin-positive cells detected by immunohistology, but levels declined thereafter. Prohormone convertase $1 / 3$ was elevated at days 3 and 7 . In hyperglycaemic rats, fasting blood glucose was lower at days 1, 3 and 7 but not thereafter, and body weight was maintained to day 28 . We conclude that hydrodynamic gene delivery of multiple transcription factors to rat liver can initiate transdifferentiation to pancreatic $\beta$ cells, but the process is reversible and probably requires more sustained transcription factor expression.

Journal of Endocrinology (2012) 214, 277-288

\section{Introduction}

The introduction of insulin therapy for type 1 diabetes in the 1920s represented a monumental advance (Banting et al. 1922). However, in spite of increasingly sophisticated approaches to regulating blood glucose with exogenous insulin (Hovorka et al. 2010, Renard 2010), optimal blood glucose control remains difficult. As a consequence, serious late complications (e.g. renal failure) are common in diabetic patients.

The only approach currently able to achieve physiological blood glucose control is the transplantation of pancreatic $\beta$ cells, either as islet or as whole pancreas allografts. However, the risks of lifelong immunosuppression (Matas et al. 2004) and the paucity of organ donors (Daneman 2006, Johnson et al. 2010) mean that allotransplantation cannot be regarded as a definitive therapy for type 1 diabetes. The possibility of xenogeneic pancreatic $\beta$ cells for transplantation has not been realised, mainly because of the risks of interspecies viral transfer (Patience et al. 1997, Cunningham et al. 2004) and the vigour of the rejection response to xenografts (McGregor et al. 2005). Various stem cell types are being evaluated for in vitro differentiation to pancreatic $\beta$ cells (Takahashi \& Yamanaka 2006, Byrne et al. 2007, Jiang et al. 2007, Karnieli et al. 2007), but establishing optimal conditions for differentiation, the allogenicity of embryonic stem cells and risks of neoplasia from non-differentiated cells (Piscaglia 2008) remain serious issues.

In situ transdifferentiation of some of the patient's own cells into pancreatic $\beta$ cells (Graf \& Enver 2009) bypasses the phase of pluripotency involved in most stem cell studies, thereby eliminating the risk of neoplasia. Moreover, there are neither issues with allogenicity nor requirements for expensive facilities. Based on modern knowledge of the embryonic differentiation of pancreatic $\beta$ cells (Habener et al. 2005), several groups have demonstrated the feasibility of transducing hepatocytes towards a pancreas phenotype in vivo. 
Ferber et al. (2000) gave standard E1/E4-deleted adenoviral vectors encoding rat $P d x 1$ i.v. to mice and found insulinproducing endocrine cells in the liver. These cells produced multiple pancreatic endocrine hormones but nevertheless were able to regulate blood glucose in streptozotocin-treated mice. When the experiments were repeated using 'gutless' adenoviral vectors encoding mouse $P d x 1$ (Kojima et al. 2003), the mice rapidly developed a lethal hepatitis. This was probably a consequence of transdifferentiation of transfected hepatocytes to an exocrine (as well as endocrine) pancreas phenotype, with the secretion of digestive enzymes. Expression of the down-stream transcription factor NeuroD1 avoided exocrine transdifferentiation (Kojima et al. 2003).

More recently, transdifferentiation to insulin-producing cells, without exocrine differentiation, has been achieved in mice with adenovirus delivery of multiple transcription factors: Ngn3 (Neurog3), NeuroD1 and MafA to liver (Song et al. 2007) and $P d x 1, N g n 3$ and $M a f A$ to pancreatic acinar cells in immune-deficient mice (Zhou et al. 2008). With the pancreatic acinar cells, expression of the transcription factors for only a few weeks was sufficient for irreversible transdifferentiation to morphologically distinct pancreatic $\beta$ cells with insulin granules (Zhou et al. 2008).

For a chronic disease like type 1 diabetes, with excellent short-term and medium-term therapy, risks must be low for gene therapy to be a viable option in the early phase of the disease. Given the risks posed by viral vectors (Raper et al. 2003, McCormack \& Rabbitts 2004), non-viral approaches offer significant advantages. Moreover, the liver is a much safer target organ than the pancreas. The risk of pancreatitis in fact essentially excludes the pancreas as an acceptable target in the clinic. The hydrodynamic approach requires neither viral nor non-viral vectors. It is currently the most promising nonviral approach for the clinical application of liver gene therapy, primarily because of lack of immunogenicity (Sawyer et al. 2009). Moreover, surgical techniques have been developed in large animals, which enable adequate pressurisation of individual liver segments (corresponding to $\sim 25 \%$ of the liver mass) using small volumes (equivalent to $\sim 0 \cdot 6 \%$ of body weight) without reducing venous return to the heart or obstructing blood flow through the intestines (Fabre et al. 2011). However, the requirements (in terms of levels and duration of expression of the pancreatic transcription factors in liver) for the irreversible transdifferentiation of liver cells to pancreatic $\beta$ cells are not known, other than that provided by adenoviruses is sufficient.

The level and duration of gene expression from DNA plasmids varies with the nature of the promoter, the presence of enhancer elements, plasmid copy number per cell, the propensity for DNA hypermethylation, the capacity of the plasmid to replicate in mammalian cells, the stability of the DNA plasmid in cells and other factors Jackson et al. 2006). A major challenge for the non-viral gene therapy of type 1 diabetes is to identify gene delivery systems and expression plasmids that produce the required levels and duration of gene expression in the key liver cells.

\section{Materials and Methods}

\section{Animals}

Inbred male DA strain rats (Harlan, Oxon, UK) were used at 180-220 g weight. All procedures were approved by the King's College London Ethics Committee and by the UK Home Office.

\section{Normoglycaemic rats}

Initial studies were performed on normal rats to avoid the potentially confounding effects of hyperglycaemia on insulin expression in liver (Kojima et al. 2004).

\section{Studies on hyperglycaemic rats}

Streptozotocin (Sigma-Aldrich) was prepared as a $4 \%$ solution by dissolving $20 \mathrm{mg}$ in $0.5 \mathrm{ml}$ of $10 \mathrm{mM}$ citrate, $0.15 \mathrm{M}$ $\mathrm{NaCl}, \mathrm{pH} 4.5$ (citrate buffer), at $4{ }^{\circ} \mathrm{C}$ and was administered within $10 \mathrm{~min}$ of preparation. Rats were given $25 \mathrm{mg} / \mathrm{kg}$ i.p. daily, after a $3 \mathrm{~h}$ fast. Blood glucose was measured using a portable glucose meter (Accu-check Aviva; Roche) from blood obtained by pricking the tail with a needle.

Because rats feed mainly at night, non-fasting blood glucose measurements were obtained at $\sim 0900 \mathrm{~h}$ and fasting blood glucose at $\sim 1500 \mathrm{~h}$ after removing food for $6 \mathrm{~h}$. Non-fasting and fasting blood glucose in normal rats was $6 \cdot 3 \pm 1 \cdot 2$ and $6 \cdot 2 \pm 0 \cdot 8 \mathrm{mM}$ respectively (mean \pm s.D., $n=6$ per group). Non-fasting blood glucose was measured daily during streptozotocin administration. Streptozotocin was continued on the first day that non-fasting blood glucose reached $20 \mathrm{mM}$ (usually day 5 or 6 ) and then stopped. Rats were entered into the study if the non-fasting blood glucose was $>20 \mathrm{mM}$ also on the following day and on the day of gene delivery (day 8 following the first dose of streptozotocin).

Rats were weighed three times per week between 0900 and $1000 \mathrm{~h}$.

\section{Hydrodynamic gene delivery to the rat liver via the isolated} inferior vena cava segment

This was performed under isoflurane general anaesthesia, using a Zeiss operating microscope for operator and assistant, as previously described (Sawyer et al. 2008). Briefly, a Harvard programmable syringe pump (model PHD 2000, Harvard Apparatus, Holliston, MA, USA) was used for delivery of the DNA. The inferior vena cava (IVC) segment into which the hepatic veins drain was isolated between 4-0 braided silk ties, one above and one below the liver. A 21-gauge needle was inserted into the IVC segment and the pump was activated. A volume corresponding to $2 \%$ of the body weight (i.e. $4 \mathrm{ml}$ for a $200 \mathrm{~g}$ rat) was delivered at $100 \mathrm{ml} / \mathrm{min}$. After $1 \mathrm{~min}$, the suprahepatic and then the infrahepatic ties were removed. 


\section{Expression plasmids}

Details of each plasmid are given in the Results section. Plasmids were prepared as lipopolysaccharide-free gigapreps (Qiagen), stored in aliquots at $1 \mathrm{mg} / \mathrm{ml}$ in water at $-35^{\circ} \mathrm{C}$ and diluted to the appropriate concentration in $0 \cdot 15 \mathrm{M} \mathrm{NaCl}$ just before use. For the initial studies evaluating the level and longevity of rat $P d x 1$ expression, pEPI(CMV)-pdx1 was used at $50 \mu \mathrm{g} / \mathrm{ml}$ and the other pEPI plasmids at equimolar concentrations: pEPI $(\mathrm{HCR}+$ A1AT $)-p d x 1 \quad(55 \mu \mathrm{g} / \mathrm{ml}), \quad$ pEPI(UCOE + HCR + A1AT)-pdx1 $(111 \mu \mathrm{g} / \mathrm{ml})$ and $\mathrm{pEPI}(10 \mathrm{~kb}$ A1AT $)-\mathrm{pdx} 1$ $(156 \mu \mathrm{g} / \mathrm{ml})$. CpG-depleted plasmid (pCpG)-pdx1 was used at $50 \mu \mathrm{g} / \mathrm{ml}$, which is a $\sim 1 \cdot 5$-fold molar excess over the pEPI constructs. For the combination studies with the pCpG plasmid, pCpG-pdx1, pCpG-ngn3 and pCpG-mafA were used at 50, 48 and $53 \mu \mathrm{g} / \mathrm{ml}$, which are equimolar concentrations. For the combination studies with the pEPI plasmid, $\mathrm{pEPI}(\mathrm{CMV})-\mathrm{pdx} 1$ was used at $66 \mu \mathrm{g} / \mathrm{ml}$ and the pEPI(CMV)-ngn3 and $\mathrm{pEPI}(\mathrm{CMV})-$ mafA at the equimolar concentrations of 64 and $68 \mu \mathrm{g} / \mathrm{ml}$ respectively.

\section{Harvesting of liver}

Under isoflurane general anaesthesia, the abdomen was opened and the rat exsanguinated via a needle in the abdominal aorta. The liver was immediately removed and samples were taken for various analyses. For each assay, the liver sample was taken from the same anatomical site.

\section{Preparation of total RNA from frozen liver samples}

Liver samples $(100-150 \mathrm{mg}$ ) were snap frozen in liquid nitrogen and stored at $-80{ }^{\circ} \mathrm{C}$. The frozen sample was placed into $2 \mathrm{ml}$ ice-cold TRIzol (Invitrogen) and homogenised with a ground glass homogeniser. Total RNA was extracted using chloroform/isoamylalcohol precipitated with isopropanol, washed in ethanol, dissolved in RNase/DNase-free water and stored in aliquots at $-80^{\circ} \mathrm{C}$.

\section{Preparation of $c D N A$}

Total RNA $(10 \mu \mathrm{g})$ was subjected to two rounds of DNase treatment (Applied Biosystems) to remove any contaminating chromosomal or plasmid DNA. DNA-free RNA $(2 \mu \mathrm{g})$ was converted to cDNA using random hexamers with a high-capacity cDNA RT kit (Applied Biosystems) and diluted to $100 \mu \mathrm{l}$ in RNase/DNase-free water. This was stored at $-35{ }^{\circ} \mathrm{C}$.

\section{TaqMan quantitative PCR}

TaqMan PCRs were performed in duplicate, including RT minus controls, using a 7900 HT Fast Real-Time PCR system (Applied Biosystems). The fluorescent marker was 6-carboxyfluorescein (FAM) at the $5^{\prime}$ end of probes with a non-fluorescent quencher (NFQ) at the $3^{\prime}$ end. Rat glyceraldehyde-3-phosphate delydrogenase (GAPDH) levels were used as internal controls to normalise RNA levels, and the data were analysed using relative quantification.

To compare levels of $P d x 1$ expression from different expression plasmids, primers and probes were based on the coding region of Pdx1 (forward primer, 5'-CTCCCTTTCCCGTGGATGAA- $3^{\prime}$, reverse primer, $5^{\prime}$-CGGTTCTGCTGCGTATGC-3'; fluorescent probe, $5^{\prime}$ (FAM)-CCTGCCCACTGGCTTT-(NFQ) $3^{\prime}$ ). To evaluate rat insulin-1, insulin-2 and GAPDH, primers and fluorescent probes were provided by Applied Biosystems.

\section{SYBR Green PCR}

Power SYBR Green PCR master mix (Applied Biosystems, code: 4367659) was used. Primers were based on the $3^{\prime}$ UTR of rat prohormone convertase 1/3: forward primer, $5^{\prime}$-CCTTCTCTTAATATGCCAAC- $3^{\prime}$ and reverse primer, $5^{\prime}$-GCTACTAATCTCACTCAAAGC- $3^{\prime}$ gave 143 bp PCR product. A dissociation curve was run to ensure that a single PCR product was obtained.

\section{Semi-quantitative PCR}

Semi-quantitative PCRs were performed using Amplitag GoldDNA polymerase (Applied Biosystems) in an MJ Research Tetrad PTC-225 thermocycler (GMI, Inc., MN, USA). cDNA ( $2 \mu \mathrm{l}$; corresponding to $40 \mathrm{ng}$ cellular RNA) was used as template, and reaction products were visualised using ethidium bromide on 1.5\% agarose gels. GAPDH was used as an internal control. Pancreatic endocrine markers (glucagon, insulin-1, insulin-2, somatostatin and pancreatic polypeptide), pancreatic exocrine markers (elastase and trypsin), pancreatic $\beta$ cell markers (Kir6.2 and the L type, voltage-gated calcium channel) and pancreatic transcription factors $(P d x 1, N e u r o D 1, N k x 2.2$ and $N k \times 6.1)$ were evaluated. The primers are listed in Supplementary Table 1, see section on supplementary data given at the end of this article. Normal liver, normal pancreas and the INS-1 rat insulinoma cell line were used as controls.

\section{DNA expression constructs}

DNA polymerase from high-fidelity PCR selection kit (Invitrogen) was used to generate coding sequences and functional elements. These were cloned into the TOPO-XL-PCR transfer vector (Invitrogen) and sequenced (GATC-Biotech Ltd., Germany) to confirm accuracy of the PCR, using NCBI (GenBank) as the reference sequence. When DNA was subcloned into expression constructs, the ligation sites were sequenced to confirm fidelity of the ligation. 


\section{Immunohistology}

Rabbit antisera to human PDX1, mouse NGN3 and human insulin (codes H-140: SC-25403; D-15-R:SC13794-R and H-86:SC-9168 respectively; Santa Cruz Biotechnology, Inc.) and rabbit antisera to mouse MAFA (code A300-611A; Bethyl Laboratories, Inc., Montgomery, TX, USA) were used. These antisera cross-react strongly with the rat homologues. A mouse IgG1 monoclonal antibody to rat $\mathrm{C}$ peptide not reactive to rat proinsulin (code NBP1-05433, Novus Biologicals, Cambridge, UK) was used. Normal rabbit IgG or the F15-42-1 mouse IgG1 monoclonal antibody to human Thy-1 (McKenzie \& Fabre 1981) was used as the negative control. Frozen sections (8 $\mu \mathrm{m}$ thickness) were placed on polylysine-coated slides (Merck) and air-dried overnight. The sections were fixed in acetone and stained using the immunoperoxidase technique with peroxidase-labelled goat anti-rabbit immunoglobulin or rabbit anti-mouse immunoglobulin as appropriate (Dako), and counterstained with Harris' hematoxylin using standard techniques.

\section{Results}

\section{Expression constructs}

Four expression constructs were based on the pEPI plasmid, the key functional elements of which are a CMV promoter and a $\sim 2 \mathrm{~kb}$ scaffold/matrix attachment region (S/MAR) from the human $\beta$ interferon gene (Baiker et al. 2000). The $\mathrm{S} / \mathrm{MAR}$ confers several properties, including the capacity for episomal replication (Jenke et al. 2004). pEPI was modified by excising the gene for the neomycin/kanamycin fusion protein and replacing it with a kanamycin resistance gene subcloned from the TOPO plasmid (Invitrogen). This avoids in vivo expression of the neomycin resistance gene, which encodes a potentially immunogenic bacterial protein. This plasmid was designated $\mathrm{pEPI}\left(\right.$ neo $\left.^{-}\right)$.

Detailed steps for constructing the DNA expression plasmids are given in Supplementary Materials and Methods, see section on supplementary data given at the end of this article. Briefly, rat $P d x 1$ cDNA was obtained by PCR and replaced the gene for green fluorescent protein (GFP) in pEPI(neo $\left.{ }^{-}\right)$. This plasmid was designated pEPI(CMV)-pdx1 (6927 bp) (Fig. 1A). pEPI(CMV)-ngn3 (6720 bp) and pEPI(CMV)-mafA (7160 bp) were similarly constructed.

Argyros et al. (2008) have reported that luciferase gene expression in mouse liver is prolonged by replacing the CMV promoter of $\mathrm{pEPI}$ with a short alpha1-antitrypsin promoter and a liver-specific enhancer. We obtained the ApoE enhancer/alpha1-anti-trypsin promoter by PCR from the PBS-HCRHPI-A plasmid (Miao et al. 2000) and replaced the CMV promoter in $\mathrm{pEPI}(\mathrm{CMV})-\mathrm{pdx} 1$ with this promoter to produce $\mathrm{pEPI}(\mathrm{HCR}+\mathrm{A} 1 \mathrm{AT})-\mathrm{pdx} 1$ (7514 bp) (Fig. 1B).
The ubiquitous chromatin-opening element (UCOE; Antoniou et al. 2003) prevents methylation of integrated plasmids (Lindahl \& Antoniou 2007) but has not previously been evaluated for episomal gene expression in vivo. A UCOE was cloned into $\mathrm{pEPI}(\mathrm{HCR}+\mathrm{A} 1 \mathrm{AT})-\mathrm{pdx} 1$ adjacent to the ApoE enhancer to produce pEPI(UCOE+HCR+ A1AT)-pdx1 (11 756 bp) (Fig. 1C).

$\mathrm{A} \sim 10 \mathrm{~kb}$ length of mammalian genome sequence is likely to contain an origin of replication (Gilbert 2004, Hibbitt et al. 2009) and also is less likely to undergo hypermethylation and gene silencing. For these reasons, $10 \mathrm{~kb}$ of the human alpha1-antitrypsin promoter was obtained by PCR and replaced the CMV promoter in $\mathrm{pEPI}(\mathrm{CMV})-\mathrm{pdx} 1$ to produce $\mathrm{pEPI}(10 \mathrm{~kb}$ A1AT)-pdx1 (16 $414 \mathrm{bp}$ ) (Fig. 1D).

$\mathrm{CpG}$ depletion of plasmids is that are known to prolong gene expression (Yew et al. 2002) $P d x 1, N g n 3$ and Maf $A$ were cloned into the $\mathrm{pCpG}$ plasmid (InvivoGen, Toulouse, France), which is completely devoid of $\mathrm{CpG}$ dinucleotides, to give pCpG-pdx1 (4477 bp) (Fig. 1E), pCpG-ngn3 (4270 bp) and pCpG-mafA (4710 bp).

\section{Quantitative kinetics of $\mathrm{Pdx} 1$ expression}

The use of a rat protein for in vivo gene expression studies on rats removes the possibility of immune responses to the commonly used immunogenic reporter genes (Limberis et al. 2009, Wang et al. 2009).

For the pEPI constructs, PCR primers and fluorescent probe for TaqMan PCR were based in the plasmid-derived $5^{\prime}$ UTR and spanned the exon-exon junction (Supplementary Fig. $1 \mathrm{~A}$ and $\mathrm{B}$, see section on supplementary data given at the end of this article). For each plasmid, levels of $P d x 1$ expression are given relative to day 1 (Fig. 2A, B, C, D and E). With pEPI(CMV)-pdx1, Pdx1 levels fell $\sim 150$-fold by day 3 (Fig. 2A). Replacement of the CMV promoter with the ApoE locus control region plus short alpha1-antitrypsin promoter (Fig. 2B) or the $10 \mathrm{~kb}$ genomic alpha1-antitrypsin promoter (Fig. 2C) gave more sustained levels of $P d x 1$ expression, with $P d x 1$ levels at $\sim 20 \%$ of day 1 levels at day 14 . Adding a UCOE element to $\mathrm{pEPI}(\mathrm{HCR}+\mathrm{AIAT})-\mathrm{pdx} 1 \mathrm{did}$ not alter the pattern of expression, except that the level of expression between days 14 and 28 appeared to be sustained (Fig. 2D).

The pCpG (Fig. 2E) behaved similarly to the pEPI plasmids without the viral promoter. The PCR primers and fluorescent probe for TaqMan PCR for $p C p G-p d x 1$ were from the coding region of $P d x 1$ (see Materials and Methods section) and therefore would not distinguish plasmid-derived $P d x 1$ from endogenous $P d x 1$. However, using primers and probe specific for the $3^{\prime}$ UTR of endogenous pdx1 (Supplementary Fig. 1C), no endogenous $P d x 1$ was detected by TaqMan PCR (data not shown).

A comparison of the levels of $P d x 1$ expression with the five constructs is given in Fig. 2F. For this figure, all samples in Fig. 2A, B, C, D and E were analysed on the same plate using primers and fluorescence probe based on the coding region of $P d x 1$ (see Materials and Methods section). Levels are given 

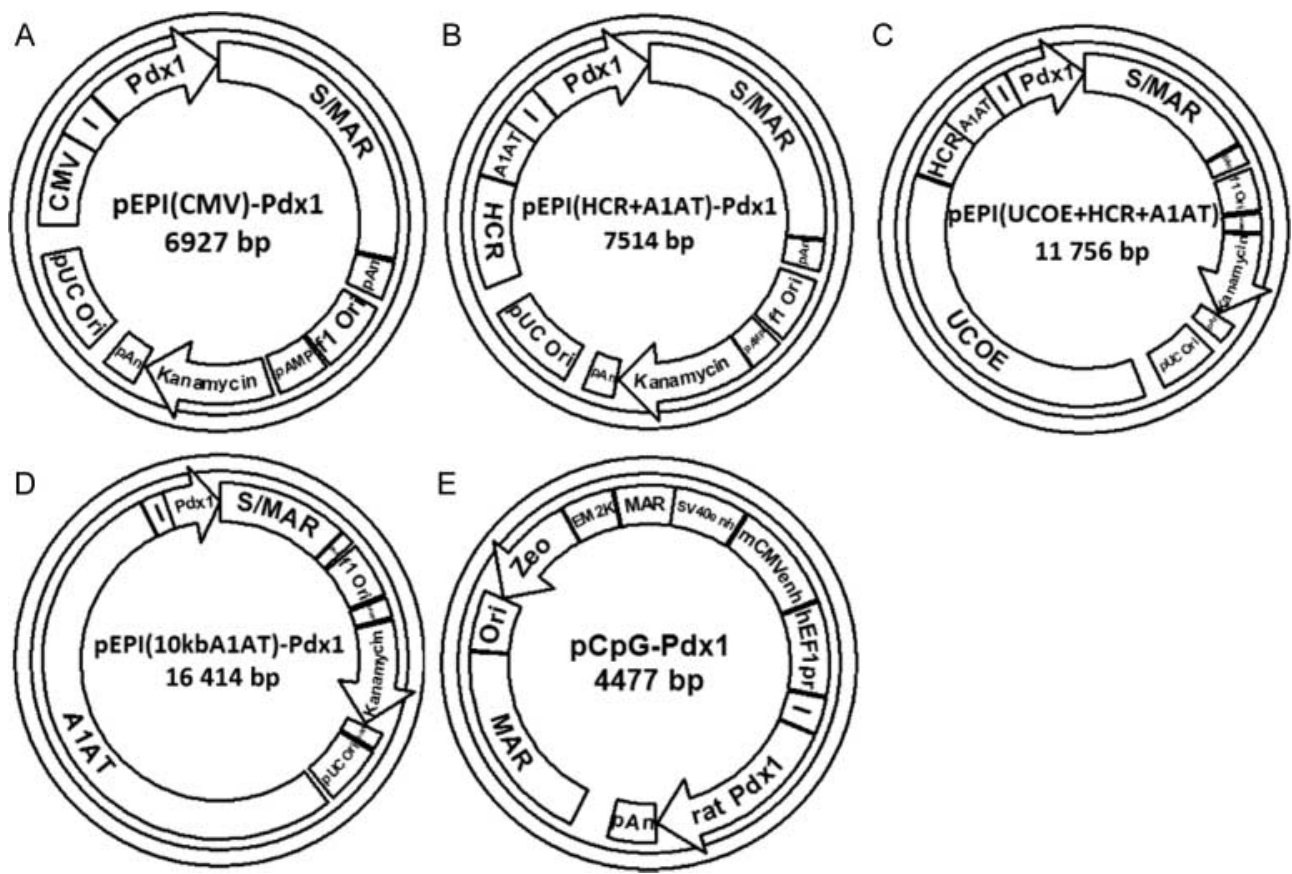

Figure 1 Expression plasmids for rat $P d x 1$. (A) The pEPI plasmid with a $\sim 2 \mathrm{~kb}$ S/MAR from the human $\beta$ interferon gene (Baiker et al. 2000, Sawyer et al. 2008) was modified by replacing the composite neomycin/kanamycin resistance gene with a kanamycin resistance gene under a bacterial promoter. The gene for GFP was replaced with rat pdx 1 to give $\mathrm{pEPI}(\mathrm{CMV})-\mathrm{pdx} 1$. I indicates an intron in the $5^{\prime}$ UTR. pAn indicates a polyadenylation signal. Note that the S/MAR is within the $P d x 1$ transcription unit. (B) The CMV promoter of pEPI(CMV)-pdx1 was replaced with the alpha1-antitrypsin promoter/ApoE locus control region of PBS-

HCRHPI (Argyros et al. 2008) to give pEPI(HCR + A1AT) - pdx1. (C) The HNRPA2B1/CBX3 UCOE (Miao et al. 2000) was cloned into the $\mathrm{pEPI}(\mathrm{HCR}+\mathrm{A} 1 \mathrm{AT})-p d \times 13^{\prime}$ to the enhancer to produce $\mathrm{pEPI}(\mathrm{UCOE}+\mathrm{HCR}+$ $\mathrm{A} 1 \mathrm{AT})-\mathrm{pdx} 1$. (D) The CMV promoter of $\mathrm{pEPI}(\mathrm{CMV})-\mathrm{pdx} 1$ was replaced with a $\sim 10 \mathrm{~kb}$ genomic promoter of human alpha1-antitrypsin to produce pEPI(10 kb A1AT)-pdx1. (E) Rat $P d x 1$ was cloned into pCpG, an expression plasmid completely devoid of CpG dinucleotides and with an EF-1 promoter (hEF1 pr; InvivoGen, Inc.) to produce $\mathrm{pCpG}-\mathrm{pdx} 1$. I, $\mathrm{pAn}$ and MAR as earlier. $\mathrm{pAn}$ indicates a polyadenylation signal. Note that the S/MAR is not within the $P d x 1$ transcription unit.

relative to $\mathrm{pEPI}(\mathrm{CMV})-\mathrm{pdx} 1$ at day 1. $\mathrm{pEPI}(\mathrm{CMV})-\mathrm{pdx} 1$ and $\mathrm{pCpG}-\mathrm{pdx} 1$ had the highest levels of expression at day 1 , with little difference between them. Removal of the CMV promoter from $\mathrm{pEPI}$ resulted in markedly lower levels of gene expression at day $1(P=0.003$, unpaired Student's $t$-test for comparisons of $\mathrm{pEPI}(\mathrm{CMV})$ with each of the other three pEPI plasmids). Thus, although the three pEPI plasmids without a CMV promoter gave a more sustained level of $P d x 1$ expression (Fig. 2B, C, D and E), the actual level of expression was much lower (Fig. 2F). The pCpG plasmid by contrast
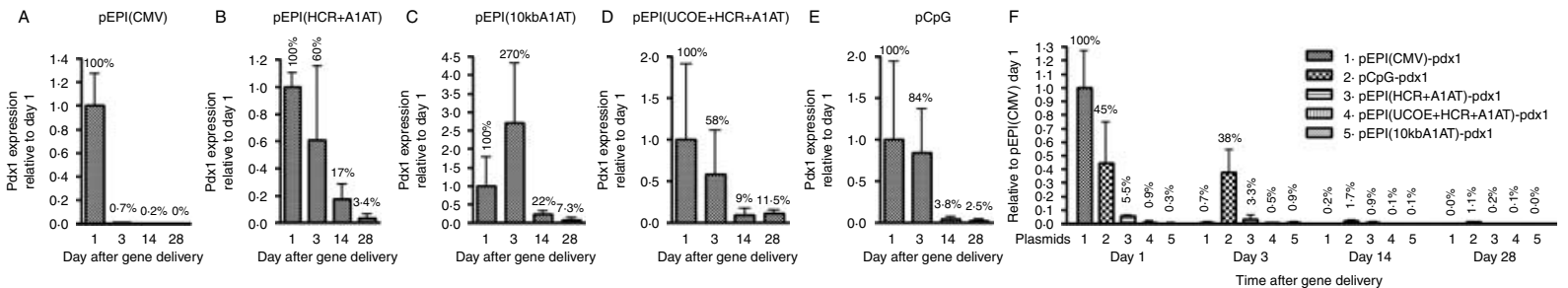

Figure 2 Quantitative kinetics of $P d x 1$ expression from different plasmids. The five expression plasmids were delivered to the livers of normal DA rats using the IVC segment hydrodynamic approach, with volumes corresponding to $2 \%$ of body weight at $100 \mathrm{ml} / \mathrm{min}$. $\mathrm{pEPI}(\mathrm{CMV})-\mathrm{pdx} 1$ was used at $50 \mu \mathrm{g} / \mathrm{ml}$ in $0.15 \mathrm{M} \mathrm{NaCl}(\mathrm{A})$ and the other $\mathrm{pEPI}$ plasmids in the equimolar concentrations of 55,156 and $111 \mu \mathrm{g} / \mathrm{ml}$ for (B) to (D) respectively. $\mathrm{pCpG}-\mathrm{pdx} 1$ was used at $50 \mu \mathrm{g} / \mathrm{ml}$ (E), which is a $\sim 1.5$ molar excess over the pEPI plasmids. Groups of three (pEPI plasmids) or four (pCpG plasmid) rats were killed at days 1, 3, 14 and 28 after gene delivery, and the livers examined by TaqMan PCR for $P d x 1$ expression, using primers and probe from the $P d x 1$ coding sequence (see Materials and Methods section). Each sample was assayed in duplicate. Values are the mean \pm 1 s.D. calculated relative to day 1 . In (F), all 64 rats shown in (A, B, C, D and E) were evaluated simultaneously, and values are given relative to day 1 for $\mathrm{pEPI}(\mathrm{CMV})-\mathrm{pdx} 1$. In all rats, RT minus PCR was negative. 
gave a relatively high level of $P d x 1$ expression sustained for several days.

TaqMan PCR for endogenous $P d x 1$ was performed in all 64 rats shown in Fig. 2F, but none was detected.

\section{Visualisation of transgene expression}

As expected from studies with reporter genes (Sawyer et al. 2008, 2009), $P d x 1$ expression was seen in isolated scattered cells (Fig. 3).

The use of $\boldsymbol{P d} \boldsymbol{x} \mathbf{1}$ alone Using adenoviral vectors, $P d x 1$ alone (Ferber et al. 2000, Kojima et al. 2003) and Ngn3 with
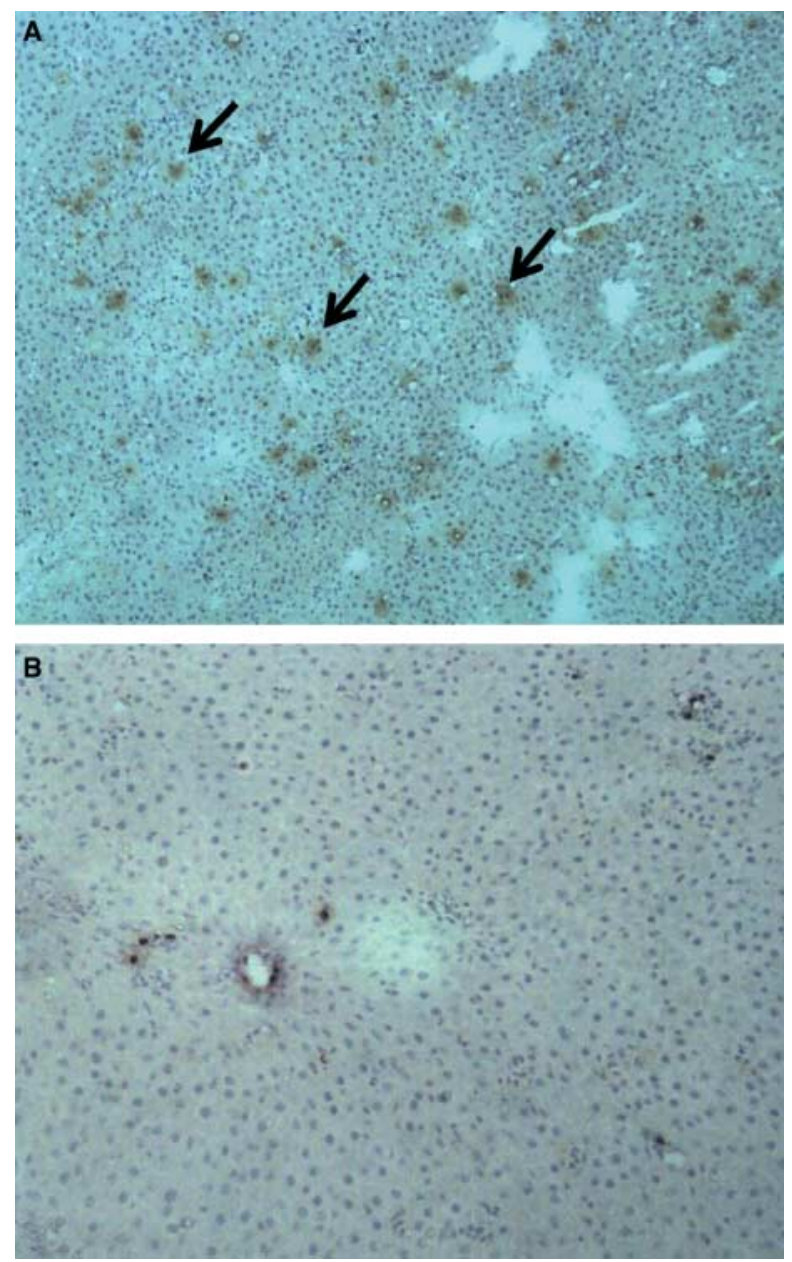

Figure 3 Visualisation of transgene expression in liver after hydrodynamic delivery. Frozen sections of liver taken 1 day after delivery of $\mathrm{pEPI}(\mathrm{CMV})-\mathrm{pdx} 1$ to normal DA rats were stained using the immunoperoxidase technique and rabbit antibodies to Pdx1 (A) or normal rabbit $\lg (\mathrm{B})$. Some of the positive cells are marked with an arrow. Very similar results were obtained with livers from rats given the $\mathrm{pEPI}(\mathrm{CMV})-$ ngn3 or $\mathrm{pEPI}(\mathrm{CMV})$-mafA plasmids (data not shown). None of the antibodies stained normal liver (data not shown). A $\times 100 ; B \times 200$. the growth factor $\beta$-cellulin (Yechoor et al. 2009) have resulted in liver to pancreatic $\beta$ cell transdifferentiation. As an initial screen for differentiation towards pancreatic $\beta$ cells, all 64 rats shown in Fig. 2 were screened by TaqMan PCR for rat insulin-1, rat insulin-2 and endogenous rat $P d x 1$. In no case was any expression noted (data not shown).

The use of MafA alone As MafA appears late in pancreatic $\beta$-cell differentiation (Habener et al. 2005), we evaluated pCpG-mafA alone. Groups of three DA rats were given pCpG-mafA, and livers were harvested at days 1, 3, 7, 14 and 28. In none of the 15 rats was insulin-1, insulin-2 or endogenous $P d x 1$ seen by TaqMan PCR (data not shown).

The use of multiple transcription factors The pEPI(CMV) and pCpG plasmids encoding Ngn3 and MafA gave excellent transgene expression at day 1 following hydrodynamic delivery of single constructs to the liver, as shown by immunohistology (as in Fig. 3) and semiquantitative PCR (data not shown). When Pdx1, Ngn3 and $M a f A$ were given together, either in the $\mathrm{pEPI}(\mathrm{CMV})$ plasmid (Fig. 4A) or pCpG plasmid (Fig. 4B and C), insulin-2 expression was readily seen in the transfected livers. With pEPI(CMV), insulin-2 was not detectable at day 1, peaked over days 3, 7 and 14 and returned to background levels by day 28 (Fig. 4A). Insulin-2 levels were $\sim 50$-fold higher with pCpG at days 3 and 7, with substantial insulin-2 expression at day 1 (Fig. 4B). Results for individual rats receiving $\mathrm{pCpG}$ are given in Fig. 4C. Given the $\sim 10$ - to 20 -fold larger size of liver in relation to pancreas, the insulin mRNA content of the livers at days 3 and 7 was approximately equal to that of pancreas. However, insulin-2 levels were declining at days 14 and 28 relative to days 3 and 7 . This suggests that, if the transdifferentiation process had been initiated, it had not reached the stage of irreversibility.

PDX1 and MAFA both bind to the insulin gene promoter and are involved in activation of transcription of the insulin gene (Aramata et al. 2005). However, neither factor alone induced insulin expression (see above). The insulin gene expression seen in Fig. 4 therefore probably represents the result of a more complex transdifferentiation process. To investigate this further, the presence of other pancreatic $\beta$ cell proteins was evaluated. The results in Fig. 5 demonstrate that the prohormone convertase $1 / 3$, essential for processing of inactive proinsulin to insulin, was transiently elevated on days 3 and 7 after the multiple factors in the pCpG plasmid but not the pEPI plasmid. This is consistent with gene delivery initiating a process of transdifferentiation which, however, reversed in the second week.

In none of the 35 rats shown in Fig. 4 was endogenous $P d x 1$ detected by TaqMan PCR. Very low levels of insulin-1 were seen at day 3 in the group receiving the $\mathrm{pCpG}$ plasmid (data not shown).

Using transgene-specific PCR primers, the expression of $P d x 1, N g n 3$ and $M a f A$ was evaluated in the livers of rats given pCpG-pdx1, pCpG-ngn3 and pCpG-mafA together 
A

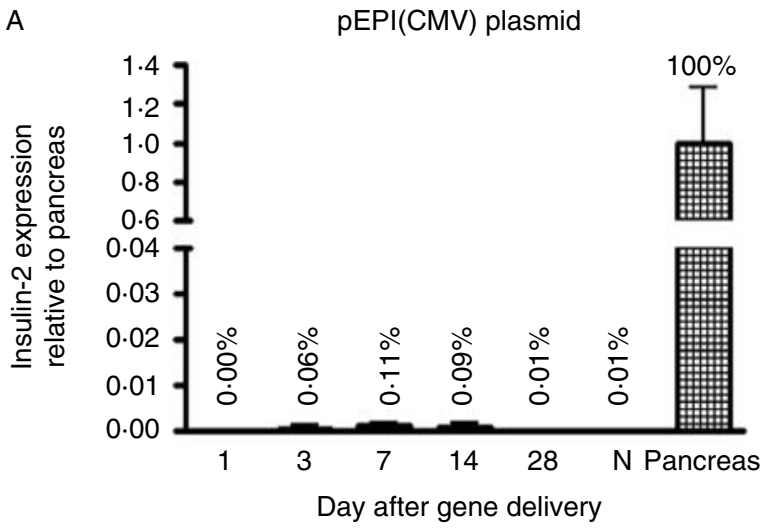

B

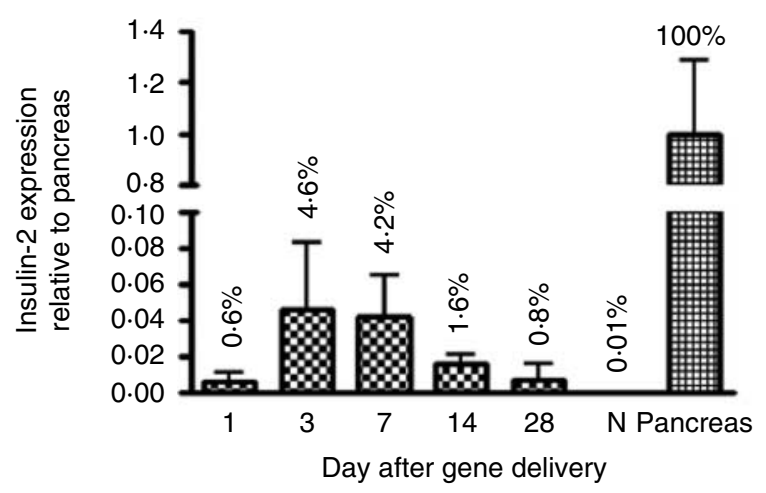

C

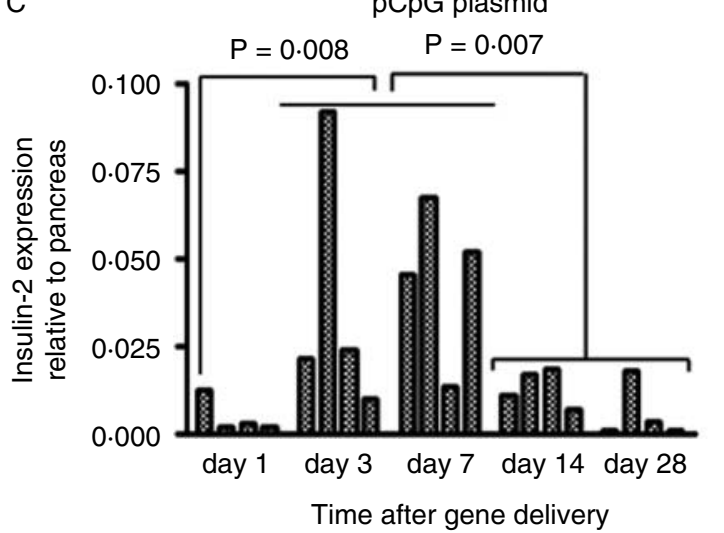

Figure 4 Quantitative kinetics of insulin expression in liver after administration of multiple transcription factors. $\mathrm{pEPI}(\mathrm{CMV})-\mathrm{pdx}$ 1, pEPI(CMV)-ngn3 and pEPI(CMV)-mafA (A) or pCpG-pdx1, pCpG-ngn3 and pCpG-mafA (B) were delivered to normal DA rats using the IVC segment hydrodynamic approach. Livers were harvested at days $1,3,7,14$ and 28 , with three or four rats per group. TaqMan PCR for insulin-2 expression in all 35 rats is shown, relative to insulin-2 expression in normal pancreas. Normal liver (N) was included as a control. Each rat was assayed in duplicate, and the results are given as the mean \pm s.D. for each group of four rats. $\operatorname{In}(\mathrm{C})$, results for individual rats of the $\mathrm{pCpG}$ group are given. The Mann-Whitney $U$ test was used for the statistical comparisons.

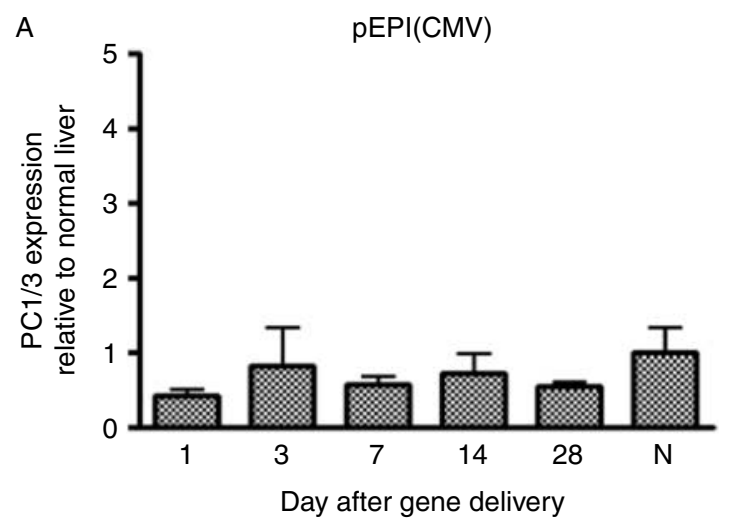

B $\quad p C p G$

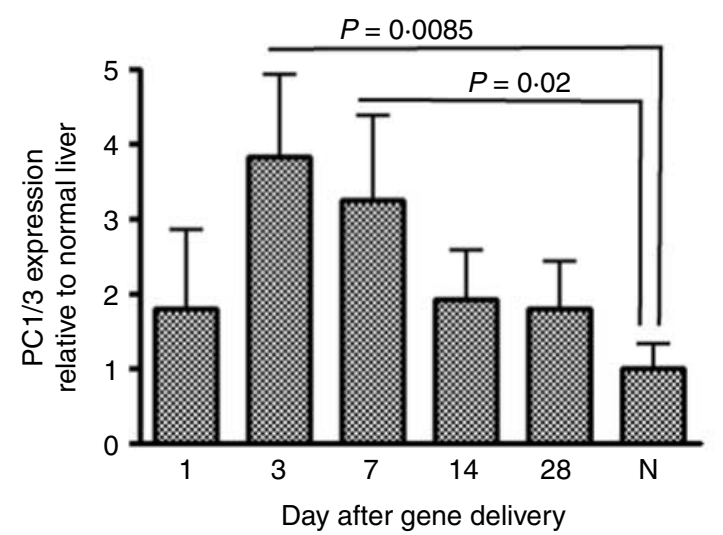

Figure 5 Quantitative kinetics of prohormone convertase 1/3 expression after administration of multiple transcription factors. $p E P I(C M V)-p d x 1, p E P I(C M V)-n g n 3$ and pEPI(CMV)-mafA (A) or $p C p G-p d x 1, p C p G-n g n 3$ and pCpG-mafA (B) were delivered to normal DA rats using the IVC segment hydrodynamic approach. Livers were harvested at days $1,3,7,14$ and 28, with three or four rats per group. These are the same rats as evaluated in Fig. 4. SYBR Green quantitative PCR for expression of prohormone convertase $1 / 3$ is shown relative to expression in normal liver $(\mathrm{N})$. Each rat was assayed in duplicate, and the results are given as the mean \pm s.D. for each group of four rats. The Mann-Whitney $U$ test was used for statistical comparisons.

(Fig. 6). All three transcription factors were expressed together in the livers of all rats in the first week after gene delivery. Thereafter levels declined but were detectable in most rats at day 28 .

\section{Localisation of insulin protein in liver}

Strong insulin expression was seen in scattered cells with hepatocyte morphology in rats given the combination of pCpG-pdx1, pCpG-ngn3 and pCpG-mafA (Fig. 7B). The insulin-positive cells were more readily observable at days 3 and 7 than at days 14 and 28 after gene delivery. However, although the C-peptide was easily detectable in pancreatic islets (Fig. 7D), it could not be detected in 


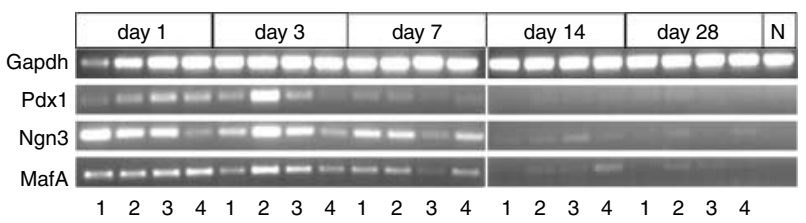

Figure 6 Transgene expression in liver after administration of multiple constructs. Livers from a normal rat $(\mathrm{N})$ and from all rats given $\mathrm{pCpG}-\mathrm{pdx} 1, \mathrm{pCpG}-\mathrm{ngn} 3$ and $\mathrm{pCpG}$-mafA together (Fig. 4B and $C$ ) were evaluated by semi-quantitative PCR for transgenic $P d x 1$, Ngn3 and MafA expression using PCR primers specific for the transgenic products. The reverse primer for the $\mathrm{pCpG}-\mathrm{pdx} 1$ and pCpG-ngn3 was from the $3^{\prime}$ UTR of plasmid origin: $5^{\prime}$-GCAATAGCATCACAAATTTCACA- $3^{\prime}$. The forward primers were from the coding sequence of the expressed gene: $5^{\prime}$-CATTGCCACCGCCACCACCT-3' for pCpG-pdx 1 and 5'-TCCCAAGCTGGTAGCCTGAGC-3' for $\mathrm{pCpG}-\mathrm{ngn} 3$ respectively. The forward primer for pCpG-mafA was from 5' UTR of plasmid origin: $5^{\prime}$-TCTCCCTCCTGTGAGTTTGGTTG- $3^{\prime}$ and the reverse primer from the coding sequence of mafA: 5'-GTCGAGGATAGCGAGCCGGGT-3'. Samples for days 1,3 and 7 were run on one gel, and for days 14 and 28 and normal liver on a different gel.

the livers of rats with insulin expressing cells as in Fig. 7B. It should be borne in mind that immunohistology is not a sensitive technique for detecting target molecules.

\section{Semi-quantitative evaluation of markers for pancreas differentiation}

Transient expression of insulin-2 in rats given the $\mathrm{pEPI}(\mathrm{CMV})$ construct (Fig. $8 \mathrm{~A}$ ) is consistent with the TaqMan quantitative assays for this group (Fig. 4A). The other pancreatic hormones (glucagon, somatostatin and pancreatic polypeptide) could not be detected. The L-type voltage-gated $\mathrm{Ca}^{++}$channel of pancreatic $\beta$ cells was detectable from day 3 , most strongly at day 7 . Interestingly, the pancreas exocrine markers (trypsin and elastase) were readily detected in some rats, suggesting transdifferentiation towards exocrine as well as endocrine pancreas. The pancreas transcription factors $(P d x 1, N e u r o D 1, N k x 2.2$ and Nkx6.1) were not detected.

Insulin-2 was easily detected in all rats given the $\mathrm{pCpG}$ construct (Fig. 8B). The other pancreatic islet hormones were not detectable, nor were pancreatic transcription factors. However, the pancreatic $\beta$-cell marker Kir6.2 (a component of the ATP-sensitive $\mathrm{K}^{+}$channel of pancreatic $\beta$ cells) and the $\mathrm{Ca}^{++}$channel were expressed from day 3 . The pancreas exocrine markers (trypsin and elastase) were also seen in most livers.

\section{Studies on hyperglycaemic rats}

To see whether the insulin detected in the transfected livers was functional and whether the addition of hyperglycaemia to the delivery of the transcription factors might enhance the transdifferentiation effect, we delivered $P d x 1, N g n 3$ and MafA together in the $\mathrm{pCpG}$ plasmid to six hyperglycaemic DA rats.
pEPI(CMV) encoding an irrelevant rat protein (lactase; at $86 \mu \mathrm{g} / \mathrm{ml}$ ) was given to five hyperglycaemic control DA rats.

There was no difference between the experimental and control groups with regard to non-fasting blood glucose (Fig. 9A). However, fasting blood glucose was lower in the experimental group on days 1, 3 and 7 after gene delivery (Fig. 9B; $P \leq 0.05$ for each of these days, Fisher's exact test). This is consistent with the high levels of insulin-2 mRNA (Fig. 4B) and the simultaneous presence of the prohormone convertase $1 / 3$ (Fig. $5 \mathrm{~B}$ ) in the livers of these rats over this period. The average weight loss from the time of gene delivery to day 25 was $12 \cdot 8 \%$ in the control group, but only $1 \cdot 1 \%$ in the experimental group (Fig. 9C; $P<0 \cdot 05$, Fisher's exact test). Body weights at days 14, 18, 21 and 25 were higher in the experimental group $(P \leq 0 \cdot 04$ for each timepoint, unpaired $t$-test). This is consistent with the low but definite expression of insulin-2 mRNA over the 25 days of the study (Figs 4B and 8B).

\section{Discussion}

We have quantitated rat $P d x 1$ expression in liver following the hydrodynamic delivery of five distinct DNA expression plasmids to normal rats. This was to determine the level and longevity of gene expression with each construct and to see whether $P d x 1$ expression alone could initiate transdifferentiation in normoglycaemic rats. Each plasmid gave markedly different patterns of expression. However, in none of the 64 rats examined by quantitative PCR over days 1, 3, 7, 14 and 28 after delivery of $P d x 1$ alone was there any insulin
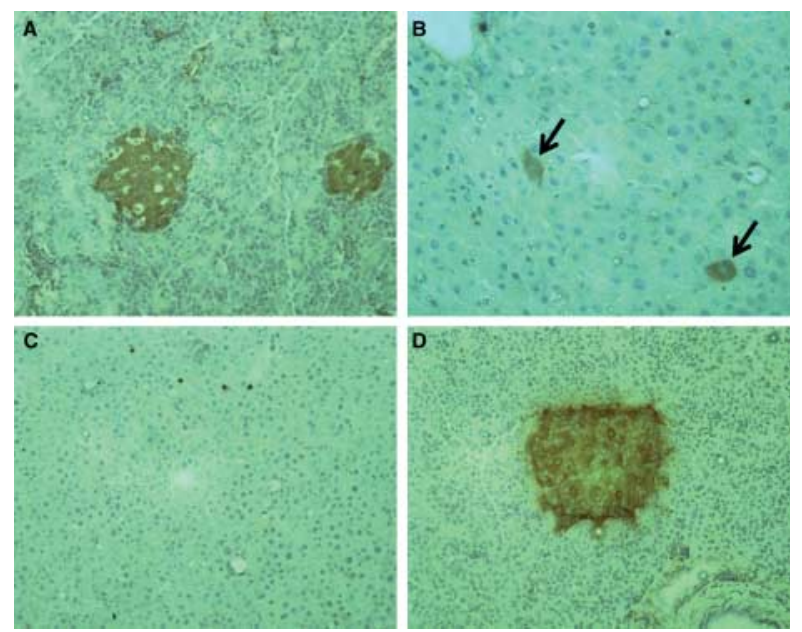

Figure 7 Immunohistological localisation of insulin in rat liver. Frozen sections of normal rat pancreas (A and D) or of liver from a normoglycaemic rat 3 days after delivery of pCpG-pdx1, pCpGngn3 and pCpG-mafA via the IVC segment hydrodynamic technique (B and $C$ ) are shown. Sections were stained with rabbit antibodies to insulin (A and $B$ ), normal rabbit $\operatorname{lgG}(\mathrm{C})$ or a mouse monoclonal antibody to rat $\mathrm{C}$-peptide (D) using the indirect immunoperoxidase technique. The insulin-positive cells in liver are marked with an arrow. A and C, $\times 200 ; B, \times 400$. 


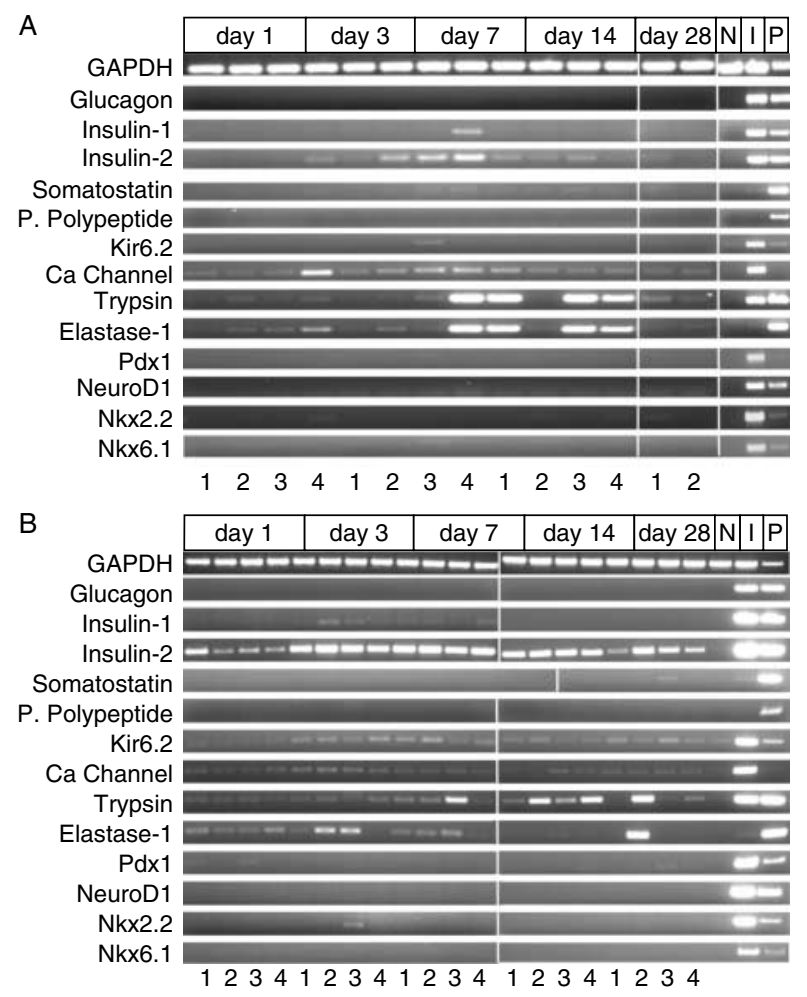

Figure 8 Semi-quantitative PCR or markers of pancreas differentiation. The rats given $\mathrm{pEPI}(\mathrm{CMV})-\mathrm{pdx} 1, \mathrm{pEPI}(\mathrm{CMV})-\mathrm{ngn} 3$ and pEPI(CMV)-mafA (A) or pCpG-pdx1, pCpG-ngn3 and pCpG-mafA (B) were evaluated by semi-quantitative PCR for markers of pancreas differentiation. The primers used for each PCR are given in Supplementary Table 1 . Note that the primers for $P d x 1$ were specific for endogenous $P d x 1$ of cellular origin. The negative control was normal liver $(\mathrm{N})$. Positive controls were the rat insulinoma cell line INS-I (I) and normal rat pancreas (P). GAPDH was used as the internal control. P. Polypeptide is pancreatic polypeptide. Kir6.2 is a component of the ATP-sensitive $\mathrm{K}^{+}$channel in pancreatic $\beta$ cells. Ca channel is the L-type voltage-gated $\mathrm{Ca}^{++}$channel of pancreatic $\beta$ cells. In (A), samples for days 1, 3, 7, 14 and 28 were run on one gel, and for the controls on a different gel. One of the samples for day 28 gave an unusual picture, which was not reproducible on mRNA taken from another part of the liver, and was therefore omitted. In (B), samples for days 1, 3 and 7 were run on one gel, and the samples for days 14 and 28 and controls on a different gel.

expression. Chen et al. (2009) have reported that the hydrodynamic delivery of $P d x 1$ alone in a commercially available plasmid (pcDNA 3.1, Invitrogen) to hyperglycaemic mice resulted in insulin-positive cells by immunohistology in the liver at week 1 but not week 2 after gene delivery. By contrast, Wang et al. (2007) did not obtain insulin expression in liver by hydrodynamic delivery of $P d x 1$ alone in hyperglycaemic mice, using a plasmid containing an alpha1-antitrypsin promoter and liver-specific enhancer (Argyros et al. 2008). It is difficult to compare these studies, other than to note the different results with the different plasmids in hyperglycaemic mice. In our studies with $P d x 1$ alone, rats rather than mice were used, and the rats were normoglycaemic in order to avoid the confounding effects of insulin expression in liver as a consequence of hyperglycaemia per se (Kojima et al. 2004).

In contrast to the results with $P d x 1$ alone, we were able to obtain strong insulin expression using the hydrodynamic
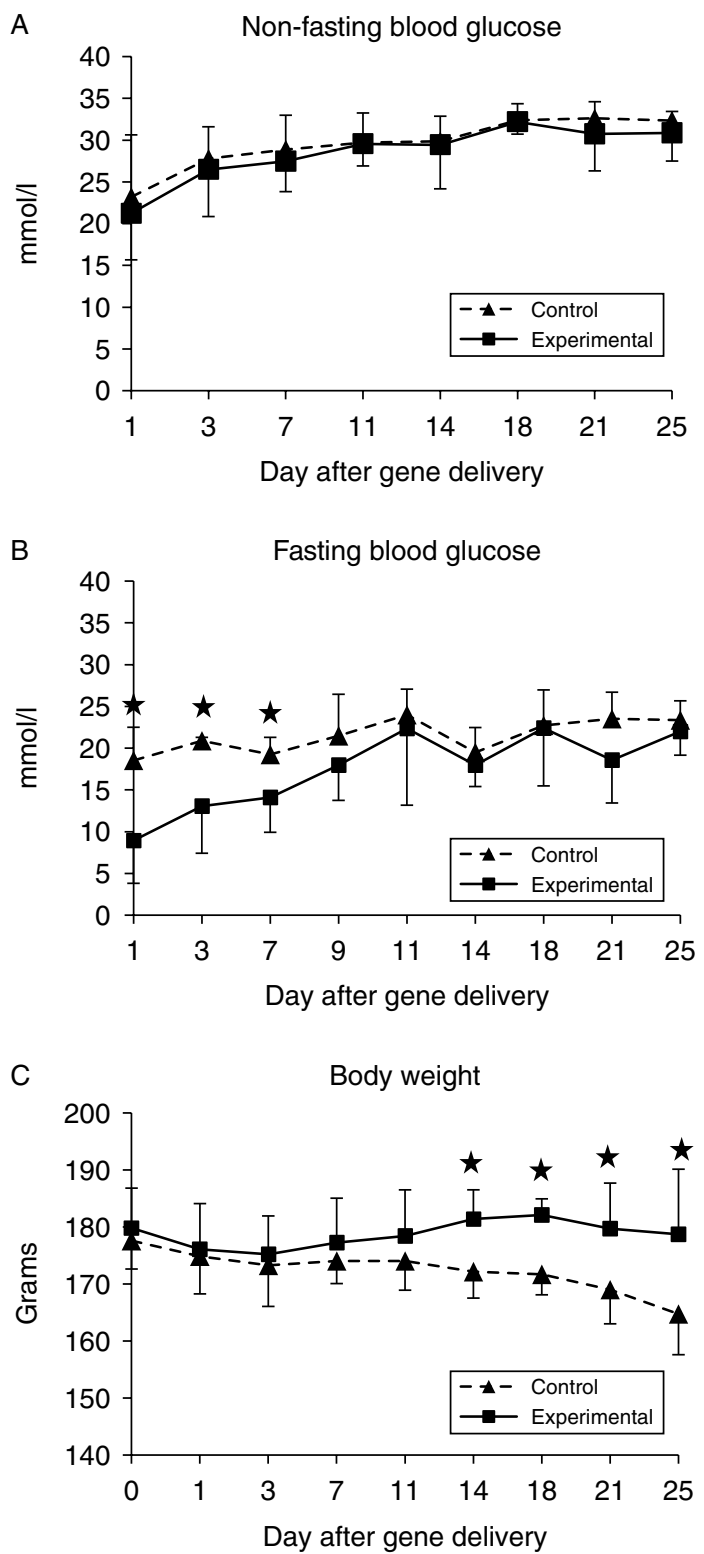

Figure 9 Studies on streptozotocin-treated hyperglycaemic rats. Hyperglycaemic DA rats (non-fasting blood glucose $\geq 20 \mathrm{mM}$ ) received $P d x 1, N g n 3$ and MafA in pCpG plasmids (experimental group $n=6)$ or $\mathrm{pEPI}(\mathrm{CMV})$ encoding rat lactase (control group $n=5)$. The mean \pm s.D. of non-fasting blood glucose (A), fasting blood glucose (B) and body weight (C) on the days indicated are shown. Weight loss from the time of gene delivery to day 25 was less in the experimental group $(1 \cdot 1 \%$ in comparison with $12.8 \%$; $P<0 \cdot 05$, Fisher's exact test). Star indicates $P \leq 0.05$ for comparisons between experimental and control groups. 
approach in normoglycaemic rats, with a combination of three transcription factors, $P d x 1, N g n 3$ and MafA. Two plasmids were evaluated for the delivery of multiple genes. Both plasmids provided comparably high levels of gene expression in liver 1 day after gene delivery, but $\mathrm{pCpG}$ gave more prolonged expression than $\mathrm{pEPI}(\mathrm{CMV})$. Both plasmids stimulated insulin expression in liver, but $\mathrm{pCpG}$ gave insulin levels $\sim 75$-fold higher than $\mathrm{pEPI}(\mathrm{CMV})$. The insulin content of the liver at days 3 and 7 was approximately equivalent to that of a pancreas. However, levels decreased substantially over days 14-28. The levels of prohormone convertase $1 / 3$ were also elevated at days 3 and 7 , but not at later times, with the $\mathrm{pCpG}$ plasmid. These data suggest that, if a transdifferentiation process had been initiated in the normoglycaemic rats, it was reversible.

It is known that hyperglycaemia promotes transdifferentiation to pancreatic $\beta$ cells (Vanderford et al. 2007). All previous published work in this area has been on hyperglycaemic animals. Our studies on hyperglycaemic rats demonstrated that at least some of the insulin produced in the liver was functionally active and therefore that it had undergone appropriate processing and release from the cell. However, lowering of the fasting blood glucose was seen only in the first week after gene delivery, suggesting that any transdifferentiation was reversible, even in the presence of hyperglycaemia.

It is uncertain whether the delivery of $P d x 1, N g n 3$ and MafA to the rat liver initiated a process of transdifferentiation, or simply directly stimulated insulin expression. The fact that multiple transcription factors were required, and that the complex process of secreting mature insulin was achieved, would suggest transdifferentiation. However, the process was reversible and inferior to the results obtained using adenoviruses to deliver the same transcription factors to mouse pancreas. It is possible that the exocrine pancreas cells, being closer embryologically to pancreatic $\beta$ cells, are a more favourable target than liver cells for transdifferentiation. However, it is also possible that the level and, in particular, the longevity of gene expression, even from our best plasmid $(\mathrm{pCpG})$, were insufficient to drive the liver cell into irreversible transdifferentiation.

Hydrodynamic gene delivery to the liver is a relatively inefficient procedure in the rat, giving of the order of 2 or $3 \%$ transfected cells (Fig. 3). This is potentially a problem in two respects. First, the number of liver cells potentially able to transdifferentiate into pancreatic $\beta$ cells is low. However, given the large size of the liver in comparison with pancreatic islets, even a low percentage of transdifferentiated liver cells is likely to be sufficient. In our study, even though we achieved only a scattering of insulin-positive cells (Fig. 7), the amount of insulin in the livers was equivalent to a pancreas. The second potential problem concerns the necessity for co-expression of all three constructs in the required target cell. Given the large number of plasmids in liver cells following hydrodynamic gene delivery - measured at $\sim 20000$ copies/cell in the mouse (Argyros et al. 2008) - it is unlikely that expression of single plasmids in individual transfected cells is a problem. This has formally been proven by the simultaneous hydrodynamic delivery in mice of two distinct plasmids, one encoding a GFP and the other a red fluorescent protein. In all cases, liver cells expressed both proteins (Richard Harbottle, Simon Waddington and Charles Coutelle, Imperial College London; personal communication of work performed in 2002). The precise nature of the liver cells that undergo transdifferentiation to pancreatic $\beta$ cells is also uncertain. If it is a relatively rare cell type, such as the oval cell, the relative susceptibility of this cell to hydrodynamic gene delivery will be crucial. However that may be, in our studies, the insulin-expressing cells frequently had a hepatocyte morphology, and the amount of insulin produced by the liver was equivalent to a pancreas. The fundamental problem highlighted by our study is unlikely to be inefficiency in the number of cells undergoing transdifferentiation, but the fact that the transdifferentiation process was not irreversible.

Semi-quantitative PCR following administration of adenoviral vectors showed strong expression of the transcription factors at 10 days after adenovirus delivery and weak expression at day 30 (Zhou et al. 2008). Thus, strong expression of the transcription factors for several weeks seems sufficient. From a practical point of view, the marked difference in efficacy between $\mathrm{pCpG}$ and $\mathrm{pEPI}(\mathrm{CMV})$ in our studies is important to note. For the future, it is possible that expression plasmids that provide more sustained gene expression than $\mathrm{pCpG}$ will be superior for irreversible transdifferentiation.

\section{Supplementary data}

This is linked to the online version of the paper at http://dx.doi.org/10.1530/ JOE-12-0033.

\section{Declaration of interest}

J-P R is an employee of InvivoGen, Inc., a company involved among other things in the development of DNA expression constructs for experimental and clinical application. There is otherwise no potential conflict of interest among the authors.

\section{Funding}

We would like to thank the Rosetrees Trust and the King's College London Business's Futures Fund for their financial support for this project. A C was supported by a scholarship from the Turkish Government.

\section{References}

Antoniou M, Harland L, Mustoe T, Williams S, Holdstock J, Yague E, Mulcahy T, Griffiths M, Edwards S, Ioannou PA et al. 2003 Transgenes encompassing dual-promoter $\mathrm{CpG}$ islands from the human TBP and HNRPA2B1 loci are resistant to heterochromatin-mediated silencing. Genomics 82 269-279. (doi:10.1016/S0888-7543(03)00107-1) 
Aramata S, Han S, Yasuda K \& Kataoka K 2005 Synergistic activation of the insulin gene promoter by the [beta]-cell enriched transcription factors MafA, beta2, and Pdx1. Biochimica et Biophysica Acta: Gene Structure and Expression 1730 41-46. (doi:10.1016/j.bbaexp.2005.05.009)

Argyros O, Wong SP, Niceta M, Waddington SN, Howe SJ, Coutelle C, Miller AD \& Harbottle RP 2008 Persistent episomal transgene expression in liver following delivery of a scaffold/matrix attachment region containing non-viral vector. Gene Therapy 15 1593-1605. (doi:10.1038/ gt.2008.113)

Baiker A, Maercker C, Piechaczek C, Schmidt SB, Bode J, Benham C \& Lipps HJ 2000 Mitotic stability of an episomal vector containing a human scaffold/matrix-attached region is provided by association with nuclear matrix. Nature Cell Biology 2 182-184. (doi:10.1038/35004061)

Banting FG, Best CH, Collip JB, Campbell WR \& Fletcher AA 1922 Pancreatic extracts in the treatment of diabetes mellitus. Canadian Medical Association Journal 12 141-146.

Byrne J, Pedersen D, Clepper L, Nelson M, Sanger W, Gokhale S, Wolf D \& Mitalipov S 2007 Producing primate embryonic stem cells by somatic cell nuclear transfer. Nature 450 497-502. (doi:10.1038/nature06357)

Chen TH, Yeh CT, Ho YP, Hsu CM, Huang CC, Shiau SS, Liang CK \& Chang ML 2009 Hydrodynamics-based transfection of pancreatic duodenal homeobox 1 DNA improves hyperglycemia and is associated with limited complications in diabetic mice. Endocrine Journal 56 783-790. (doi:10.1507/ endocrj.K09E-112)

Cunningham DA, Dos Santos Cruz GJ, Fernández-Suárez XM, Whittam AJ, Herring C, Copeman L, Richards A \& Langford GA 2004 Activation of primary porcine endothelial cells induces release of porcine endogenous retroviruses. Transplantation 77 1071-1079. (doi:10.1097/01.TP. 0000114966.20491.50)

Daneman D 2006 Type 1 diabetes. Lancet 367 847-858. (doi:10.1016/S01406736(06)68341-4)

Fabre JW, Whitehorne M, Grehan A, Sawyer GJ, Zhang X, Davenport M \& Rela M 2011 Critical physiological and surgical considerations for hydrodynamic pressurisation of individual segments of the pig liver. Human Gene Therapy 22 879-887. (doi:10.1089/hum.2010.144)

Ferber S, Halkin A, Cohen H, Ber I, Einav Y, Goldberg I, Barshack I, Seijfers R, Kopolovic J, Kaiser N et al. 2000 Pancreatic and duodenal homeobox gene 1 induces expression of insulin genes in liver and ameliorates streptozotocin-induced hyperglycemia. Nature Medicine 6 568-572. (doi:10.1038/75050)

Gilbert DM 2004 In search of the holy replicator. Nature Reviews. Molecular Cell Biology 5 848-855. (doi:10.1038/nrm1495)

Graf T \& Enver T 2009 Forcing cells to change lineages. Nature 462 587-594. (doi:10.1038/nature08533)

Habener JF, Kemp DM \& Thomas MK 2005 Minireview: transcriptional regulation in pancreatic development. Endocrinology 146 1025-1034. (doi:10.1210/en.2004-1576)

Hibbitt OC, McNeil E, Lufino MMP, Seymour L, Channon K \& Wade-Martins R 2009 Long-term physiologically regulated expression of the low-density lipoprotein receptor in vivo using genomic DNA mini-gene constructs. Molecular Therapy 18 317-326. (doi:10.1038/mt.2009.249)

Hovorka R, Allen JM, Elleri D, Chassin LJ, Harris J, Xing D, Kollman C, Hovorka T, Larsen AMF \& Nodale M 2010 Manual closed-loop insulin delivery in children and adolescents with type 1 diabetes: a phase 2 randomised crossover trial. Lancet 375 743-751. (doi:10.1016/S01406736(09)61998-X)

Jackson DA, Juranek S \& Lipps HJ 2006 Designing nonviral vectors for efficient gene transfer and long-term gene expression. Molecular Therapy 14 613-626. (doi:10.1016/j.ymthe.2006.03.026)

Jenke AC, Stehle IM, Herrmann F, Eisenberger T, Baiker A, Bode J, Fackelmayer FO \& Lipps HJ 2004 Nuclear scaffold/matrix attached region modules linked to a transcription unit are sufficient for replication and maintenance of a mammalian episome. PNAS 101 11322-11327. (doi:10.1073/pnas.0401355101)

Jiang W, Shi Y, Zhao D, Chen S, Yong J, Zhang J, Qing T, Sun X, Zhang P, Ding $M$ et al. 2007 In vitro derivation of functional insulin-producing cells from human embryonic stem cells. Cell Research 17 333-344. (doi:10.1038/ cr.2007.28)
Johnson RJ, Fuggle SV, Mumford L, Bradley JA, Forsythe JLR \& Rudge CJ 2010 A New UK 2006 National Kidney Allocation Scheme for deceased heart-beating donor kidneys. Transplantation 89 387-394. (doi:10.1097/TP. 0b013e3181c9029d)

Karnieli O, Izhar-Prato Y, Bulvik S \& Efrat S 2007 Generation of insulinproducing cells from human bone marrow mesenchymal stem cells by genetic manipulation. Stem Cells 25 2837-2844. (doi:10.1634/stemcells. 2007-0164)

Kojima H, Fujimiya M, Matsumura K, Younan P, Imaeda H, Maeda M \& Chan L 2003 NeuroD-betacellulin gene therapy induces islet neogenesis in the liver and reverses diabetes in mice. Nature Medicine 9 596-603. (doi:10.1038/nm867)

Kojima H, Fujimiya M, Matsumura K, Nakahara T, Hara M \& Chan L 2004 Extrapancreatic insulin-producing cells in multiple organs in diabetes. PNAS 101 2458-2463. (doi:10.1073/pnas.0308690100)

Limberis MP, Bell CL, Heath J \& Wilson JM 2009 Activation of transgenespecific $\mathrm{T}$ cells following lentivirus-mediated gene delivery to mouse lung. Molecular Therapy 18 143-150. (doi:10.1038/mt.2009.190)

Lindahl AM \& Antoniou M 2007 Correlation of DNA methylation with histone modifications across the HNRPA2B1-CBX3 ubiquitously-acting chromatin open element (UCOE). Epigenetics 2 227-236. (doi:10.4161/ epi.2.4.5231)

Matas AJ, Kandaswamy R, Humar A, Payne WD, Dunn DL, Najarian JS, Gruessner RWG, Gillingham KJ, McHugh LE \& Sutherland DER 2004 Long-term immunosuppression, without maintenance prednisone, after kidney transplantation. Annals of Surgery 240 510-516. (doi:10.1097/01.sla. 0000137140.79206.d0)

McCormack MP \& Rabbitts TH 2004 Activation of the T-cell oncogene LMO2 after gene therapy for X-linked severe combined immunodeficiency. New England Journal of Medicine 350 913-922. (doi:10.1056/ NEJMra032207)

McGregor CGA, Davies WR, Oi K, Teotia SS, Schirmer JM, Risdahl JM, Tazelaar HD, Kremers WK, Walker RC \& Byrne GW 2005 Cardiac xenotransplantation: recent preclinical progress with 3-month median survival. Journal of Thoracic and Cardiovascular Surgery 130 844-851. (doi:10.1016/j.jtcvs.2005.04.017)

McKenzie JL \& Fabre JW 1981 Human Thy-1: unusual localization and possible functional significance in lymphoid tissues. Journal of Immunology $126843-850$.

Miao CH, Ohashi K, Patijn GA, Meuse L, Ye X, Thompson AR \& Kay MA 2000 Inclusion of the hepatic locus control region, an intron, and untranslated region increases and stabilizes hepatic factor IX gene expression in vivo but not in vitro. Molecular Therapy 1 522-532. (doi:10.1006/mthe.2000.0075)

Patience C, Takeuchi Y \& Weiss RA 1997 Infection of human cells by an endogenous retrovirus of pigs. Nature Medicine 3 282-286. (doi:10.1038/ nm0397-282)

Piscaglia AC 2008 Stem cells, a two-edged sword: risks and potentials of regenerative medicine. World Journal of Gastroenterology 14 4273-4279. (doi:10.3748/wjg.14.4273)

Raper SE, Chirmule N, Lee FS, Wivel NA, Bagg A, Gao GP, Wilson JM \& Batshaw ML 2003 Fatal systemic inflammatory response syndrome in a ornithine transcarbamylase deficient patient following adenoviral gene transfer. Molecular Genetics and Metabolism 80 148-158. (doi:10.1016/ j.ymgme.2003.08.016)

Renard E 2010 Closed-loop insulin delivery: is the holy grail near? Lancet 375 702-703. (doi:10.1016/S0140-6736(09)62165-6)

Sawyer GJ, Grehan A, Dong X, Whitehorne M, Seddon M, Shah AM, Zhang X, Salehi S \& Fabre JW 2008 Low-volume hydrodynamic gene delivery to the rat liver via an isolated segment of the inferior vena cava: efficiency, cardiovascular response and intrahepatic vascular dynamics. Journal of Gene Medicine 10 540-550. (doi:10.1002/jgm.1176)

Sawyer GJ, Rela M, Davenport M, Whitehorne M, Zhang X \& Fabre JW 2009 Hydrodynamic gene delivery to the liver: theoretical and practical issues for clinical application. Current Gene Therapy 9 128-135. (doi:10.2174/156652309787909535) 
Song YD, Lee EJ, Yashar P, Pfaff LE, Kim SY \& Jameson JL 2007 Islet cell differentiation in liver by combinatorial expression of transcription factors neurogenin-3, BETA2, and RIPE3b1. Biochemical and Biophysical Research Communications 354 334-339. (doi:10.1016/j.bbrc.2006.12.216)

Takahashi K \& Yamanaka S 2006 Induction of pluripotent stem cells from mouse embryonic and adult fibroblast cultures by defined factors. Cell 126 663-676. (doi:10.1016/j.cell.2006.07.024)

Vanderford NL, Andrali SS \& Ozcan S 2007 Glucose induces MafA expression in pancreatic beta cell lines via the hexosamine biosynthetic pathway. Journal of Biological Chemistry 282 1577-1584. (doi:10.1074/jbc. M605064200)

Wang AY, Ehrhardt A, Xu H \& Kay MA 2007 Adenovirus transduction is required for the correction of diabetes using $\mathrm{Pdx}-1$ or neurogenin-3 in the liver. Molecular Therapy 15 255-263. (doi:10.1038/sj.mt.6300032)

Wang L, Calcedo R, Wang H, Bell P, Grant R, Vandenberghe LH, Sanmiguel J, Morizono H, Batshaw ML \& Wilson JM 2009 The pleiotropic effects of natural AAV infections on liver-directed gene transfer in macaques. Molecular Therapy 18 126-134. (doi:10.1038/mt.2009.245)
Yechoor V, Liu V, Paul A, Lee J, Buras E, Ozer K, Samson S \& Chan L 2009 Gene therapy with neurogenin 3 and betacellulin reverses major metabolic problems in insulin-deficient diabetic mice. Endocrinology 150 4863-4873. (doi:10.1210/en.2009-0527)

Yew NS, Zhao H, Przybylska M, Wu IH, Tousignant JD, Scheule RK \& Cheng SH 2002 CpG-depleted plasmid DNA vectors with enhanced safety and long-term gene expression in vivo. Molecular Therapy 5 731-738. (doi:10.1006/mthe.2002.0598)

Zhou Q, Brown J, Kanarek A, Rajagopal J \& Melton DA 2008 In vivo reprogramming of adult pancreatic exocrine cells to beta-cells. Nature $\mathbf{4 5 5}$ 627-632. (doi:10.1038/nature07314)

Received in final form 26 May 2012

Accepted 6 June 2012

Made available online as an Accepted Preprint 8 June 2012 